\title{
Perception and impact of pain in the lives of elderly patients with oncological diseases
}

\author{
Percepção e impacto da dor na vida de idosos com doença oncológica
}

João Evangelista da Costa ${ }^{1}$, Clélia Albino Simpson ${ }^{1}$, Ana Elza Oliveira de Mendonça ${ }^{1}$, Deyla Moura Ramos Isoldi ${ }^{1}$, Rayanne Suelly da Costa Silva ${ }^{1}$, Nayanne Ricelli da Costa Silva ${ }^{1}$

objective: to understand the impact and changes in the routine of family relationships caused by pain in elderly patients with oncological diseases. Methods: it is a qualitative research based on oral history of life. Study participants were five elderly of the Nucleus of Hemotherapy and Hematology. Criteria of Inclusion were being assisted by the treatment team, in cancer treatment during the study period and being 60 years old or more. Results: data were collected through semi-structured interviews and analyzed using content analysis. Conclusion: it was shown that the pain caused feelings of sadness and isolation, changing the lives of the elderly and their families. Cancer and pain produced physical and psychological repercussions, affecting their lives. The success for the treatment of pain depends on the work of professionals to make the complete identification of complaints, selecting strategies and evaluating them.

Descriptors: Pain; Neoplasms; Quality of Life; Nursing.

Objetivo: compreender impacto e alterações na rotina de relações familiares causados pela dor em idosos com doença oncológica. Métodos: pesquisa qualitativa, fundamentada na história oral de vida. Participaram do estudo cinco idosos do Núcleo de Hemoterapia e Hematologia. Os critérios de inclusão foram estar em acompanhamento pela equipe assistencial, em tratamento oncológico no período do estudo e ter 60 anos de idade ou mais. Resultados: os dados foram coletados por uma entrevista semiestruturada e analisados por meio da Análise de Conteúdo. Conclusão: evidenciou-se que a dor acarretou sentimento de tristeza e isolamento, modificando a vida dos idosos e familiares. 0 câncer e a dor produziram repercussões físicas e psicológicas, afetando suas vidas. 0 sucesso para o tratamento da dor depende da atuação dos profissionais para fazerem a identificação completa das queixas, selecionar estratégias e avaliá-las.

Descritores: Dor; Neoplasias; Qualidade de Vida; Enfermagem.

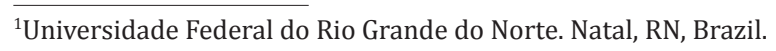




\section{Introduction}

The aging process of the Brazilian population is similar to other countries in the world, occurring mainly by the reduction in mortality rates and increased life expectancy of the population. The projections of the Brazilian Geography and Statistics Institute is that the number of elderly people should rise from 14.9 million ( $7.4 \%$ of the total population) in 2013 to 58.4 million $(26.7 \%$ of the total population), in $2060^{(1)}$.

The changing profile of diseases has contributed to the increase in the number of elderly and the infectious and parasitic diseases are no longer a major cause of morbidity and mortality of the population. There was an increase of chronic diseases such as cardiovascular disease and cancer. Cancer in the elderly now occupies a relevant domain in the global epidemiological scenario ${ }^{(2)}$.

Cancer is the name given to a set of over a hundred diseases that have in common the disordered or malignant cell growth. The causes of cancer are varied and may be internal or external to the body. External causes relate to the environment and living habits or customs, while the internal are mostly predetermined genetically, and are linked to the body's ability to defend itself from these aggressions ${ }^{(3)}$.

Around $80.0 \%$ of patients with some oncological disease and metastasis feel some kind of pain in at least two different anatomical sites, thus requiring adequate treatment. The pain becomes frequent in malignant neoplasias in all accentuated phases of the evolution, being present in $20.0 \%$ to $50.0 \%$ in the beginning of the treatment, since in addition to pain caused by cancer, therapeutics used as surgery and radiotherapy, can cause side effects. Radiotherapy can cause acute injury and late effects of tissues such as mucosal ulceration, vascular lesions, atrophy of the tissues. All of these effects are related to the total dose absorbed, the site of application and fractionation used, and they may cause pain ${ }^{(4-5)}$.

The pain is characterized as a feeling or unpleasant emotional experience and is associated to actual or potential tissue damage. The pain of acute classification lasts for less than six months, and chronic classification occurs when it persists beyond this period. For this, there are resources that mitigates and/or control pain complaints, such as use of secure analgesics, innovative techniques of analgesia and specific units for the treatment of pain. These resources improved the treatment of the pain, especially in cancer patients who experience chronic pain in their routine $\mathrm{e}^{(4,6-7)}$.

Millions of people worldwide who suffer from some kind of pain are treated insufficiently, and/or inadequately. The main reasons for this situation are due to the lack of inexperience, lack of knowledge of the simple principles of handling effective analgesics and, in many places, the unavailability of appropriate opioid analgesics. A definition of the best treatment for the pain of the elderly is needed, considering the specificities of this age group ${ }^{(5-7)}$.

It is essential to strengthen the work of nurses and other health professionals to override drug technical and technological intervention, since the care process necessarily involves an interpersonal relationship. In this context, it is imperative to consider that the pain complaint of cancer patients describes elements that cause imbalance in the treatment, causing therapeutic changes and also reflecting in the daily lives of the patients and their families ${ }^{(4.8)}$.

When there is lack of identification and undertreatment of pain in cancer patients, the physiological stress emerges, and it can interfere in the treatment. Therefore, the performance of the health care professional/nurse, independently and collaboratively, need to understand: the complete identification of the pain complaint, the selection of strategies for their control and the evaluation of the response to the strategies used ${ }^{(5,7)}$.

When discussing about pain in cancer patients, a study shows that pain is a significant concern, once it is the most feared aspect of the cancer, and may have a negative impact on quality of life of those. 
Another important point highlighted was that the pain untreated or misdiagnosed, which is very common and frequent, bringing suffering and damages the treatment ${ }^{(7,9)}$.

The success for the treatment of pain depends on a multidisciplinary approach, as well as the work of professionals who practice care in the essence of its meaning. The pain characterized as a sign of suffering generates changes in the welfare of the whole multidisciplinary team, as well as within the health organization itself, which requires the development of evaluation protocols and management of chronic and acute pain, as well as in ongoing education and training to change behavior and inadequate practices. Among these tools is the systematic use of instruments to measure and register the pain ${ }^{(4,5)}$.

The development of this study is justified by complementing the existing scientific production in the area, in order to know the impact that pain causes in the life of the elderly, whether as a diagnostic factor, or secondary to disease; but also contributes to health sectors specialized such the Nucleus of Hemotherapy and Hematology assisting the elderly with cancer and pain. Because of that, this study is guided by the following question: "What is the impact of pain complaint for the elderly with oncologic disease?"

In this perspective, the study aimed at understand the impact and the changes in the routine and in the family relations caused by the pain in elderly patients with oncological diseases.

\section{Methods}

It is a qualitative study, based on the method of oral history of life. The practice of this method leads to know the apprehension of the principles of human subjectivity through life narrative, which induces the patients to declare their experiences and meanings in their social context $\mathrm{t}^{(10)}$.

58 possible participants were cataloged for the research. However it was found that some records of the Nucleus of Hemotherapy and Hematology presented insufficient data which prevented the necessary contact to schedule the interviews. Among the participants contacted, there were 22 losses due to lack of data such as address, telephone and diagnosis, 23 patients who died prior to data collection, six did not respond to the contact and two did not agree to participate in the research. The initial sampling consisted of 12 participants, but at the end of the time allotted for selection of participants, only five elderly were identified, who, besides coping with the criteria of inclusion and exclusion, agreed to participate in the research.

All of the participants had been monitored in the Nucleus of Hemotherapy and Hematology, linked to the University Hospital in the city of Natal, Rio grande do Norte, Brazil. This service provides care to patients with hematologic disorders caused by various diseases, including cancer (solid and not solid tumors), which require specialized medical care in the area of hemotherapy and who had outpatient transfusion of blood components. The hemotherapy is the medical specialty dedicated to the collection, processing and transfusion of blood components, providing hemotherapeutic support to patients who need this therapy, commonly used by patients with oncological disease $\mathrm{e}^{(11)}$.

For this study, participants were selected through the records of the Nucleus of Hemotherapy and Hematology under the following criteria of inclusion: being assisted by the care team and under hemotherapeutic treatment; with pain related to cancer; being in cancer treatment in the study period and aged 60 years or more. As criteria of exclusion: patients who did not fit the criteria of inclusion and who did not agree to participate in the study.

Data were collected from January to March 2012, through a semi-structured interview. The instrument consisted of two parts: the first contemplating the socio-demographic data such as gender, occupation, education level, marital status and data related to the type of cancer and the location of the pain complaint. The second part presented the question: "How was 
the discovery of your illness and what changed in your life?" This methodology allows the participants to narrate their story spontaneously.

This research is a cutout of a larger study that used as a method and technique oral history of life. As data collection instrument, interviews, oral histories, the use of open questions were used, allowing the participants to report their story in the best way they could $^{(10)}$. Therefore, during the interview, the main role of the researcher was to listen and encourage the speech of the interviewee. The time of the analysis is when the researcher points to a thematic area, at work, clippings of stories that would focus the pain and its impact on the lives of the participants and their families were used.

The interviews were held in the homes of the participants, place previously chosen by them, where accounts of life were recorded in an MP3 device. The duration of the interviews varied according to the capacity of the participants without describing their life story from the changes caused by cancer. The average was 45 minutes, with several breaks, once the elderly showed great emotion when reporting the difficult times. The interviews were completely transcript.

The data of characterization of the sample were distributed in tables of the Microsoft Excel Program 2009. The qualitative data were analyzed from the Analysis of content, which is configured in three stages: pre-analysis (organization of the material and systematization of ideas); analytical description (Categorization of data in units of register) and referential interpretation (processing and interpretation of data).

To ensure the anonymity of the participants, pseudonyms were used as identifiers in the results and discussion in an ascending and sequential order, followed by an Arabic numeral, as exemplified: Participant1.

The study complied with the formal requirements contained in the national and international regulatory standards of research involving human beings.

\section{Results}

Of the five participants, three were female and two male. As for family income, four had income of a minimum wage and one with income higher than $\mathrm{R} \$$ 622.00. Regarding the level of education, a participant reported to be illiterate; one had not finished elementary school and three had high school degree. Four were married and one was a widower. All were 60 years old or more and were retired.

In the second phase, the characteristics facing the type and location of the cancer referred to by the pain complaint were identified. The two men were suffering from prostate cancer, while women, two had uterine cancer and one multiple myeloma. As for the mentioned location of the pain, two participants who reported that the pain was more frequent and intense in the pelvic region and they complained of widespread pain, one with pain in the lower limbs and one with pain the lower back region. It was observed that the spot of higher intensity of pain was linked to the disease site, that is, the location of the tumor.

From the results, two thematic axes were established through detailed analysis of the history of each participant, so entitled:

\section{Pain complaint as a precursor for cancer diagnosis and the type of treatment assigned}

The pain complaints establish symptomatic oncological location, a fact revealed by the following statements: I feel pain here in the lower area of the belly, I feel pain in the legs, I feel a lot of things. Sometimes the pain comes and goes, I feel weak, with weak arms. I was almost well, walking everywhere. Now I am not walking as I used to, now I have difficulties to walk, to see, to look at the people (Participant1). I felt a pain, a bite in the spine and the pain was growing. It started out as a simple pain that no one knew where it came from, a clinical examination was made and I went to the doctor who concluded it was a cancer. But I suffered more than a year in constant pain without reaching a conclusion. When there is a pain in this bone (left femur) it radiates to this leg here, they apply dolantina ten minutes later I feel no pain (Participant2). I felt 
a small lump and pain, I went to the doctor's appointment, and then came the result (myeloma) I went to the chemotherapy treatment (Participant3). The pain came, and I rushed to the hospital. The pain was here, here in the chest. From the throat down here to the back. I feel a lot of pain, I try a way to walk, to live and feel this problem, after these injections. I can hardly walk right here at home. I spend the whole life here, lying on this hammock. The pain is no joke. I feel pain all over. It's difficult, but sometimes I urinate and I feel that burn, but it is little. I retired because I could not stand working anymore, I had pain in the back, too (Participant4). At the beginning I felt a lot of pain in the lower area of the belly, I had strong pain three times. I did all the tests, including blood test which accused the antigen - CA 125 type of cancer. It showed that I had cancer (Participant5).

\section{Changes in the routine: a phase of loss and limitations}

The oncological disease, with the advancement of age, leads to limitations in the physiological functions of the body, making the elderly increasingly predisposed to the dependence of other in order to have care, loss of autonomy and quality of life, as can be demonstrated in the following statements: I worked and worked at the street market. I stopped working. I'm really sad, because we get sad. Because we have been sick a long time, you have to get well. We feel sad. After the disease my life changed. When I walked, it was always better, always. I see the people talk, I see the people having joy, but I, myself, it does not matter what. I lost joy (participant1). A lot changed in my life. I had to stop with everything because I had no condition to be at work and take care of the disease, because it was spreading a lot and it was affecting myself more and more each day. It is as it is now, the situation worsened and became a little more critical. And this pain was growing up I started to have more difficulties, as I have now when I walk. I'm not walking in the house (Participant2). This all interfered a lot in my life, because we do not have the responsibility of a housewife, we have to assign the obligations to others. Then it changes a lot. At the hospital, we are taken care of, but it's never like at home (Participant3). I used to do a lot of things in the house, sweeping the floor and helping the wife. I used to work a lot in the house. Today I cannot! I can hardly get anything, everything hurts, the hands hurt (Participant4). A lot changed in my life, yes, it changed. In the beginning of the disease, I got very weak, but later I kept on doing the same things, thank God, now I do everything. It's been a long while since I last went to church. The girls come here and ask when I will return (Participant5).

\section{Discussion}

Advances in areas such as economy, work, health, science, technology and innovation, among others, provide a better aging of the world population, having longevity as one of the great achievements in the twentieth century. It is worth highlighting that the very condition inherent to the aging process can provide an increase of co-morbidities in this age group of the population since it demands an increase of researches in this area.

Research in oral history seek elements that writing can not reveal, since it is the report of the memories of personal stories, facts or happenings, which makes their access hidden or explained by the participants in degrees and dimensions that affect their objective or subjective experience, such as emotions and feelings. In this study, the limiting factor was, on one hand the need to interrupt the interview in moments of intense emotion that triggered the crying and long silent pauses. On the other hand, breaks aimed at minimizing the suffering of the participants, making them return to statements with no harm.

It is worth highlight that the number of participants in this study was not presented as a requirement a priori because this method and technique emphasizes the depth of the oral report, so the collected elements were enough to understand the results and can serve as triggers to other studies and researches, contributing to the results to health, such as information material for the health professionals, fostering reflections focused on this theme, providing the understanding of human frailty of people with cancer, because it represents a delicate and incisive moment in achieving their destinations.

So, pain complaints are observed in the statements that make up the first thematic area as a precursor for the diagnosis of cancer. Pain is often 
described as a cause of suffering and loss of quality of life in patients with various diseases, including cancer ${ }^{(12) .}$.

What can be seen is that the pain complaint was present as a symptom in all statements. Therefore, being diagnosed with a serious illness such as cancer, by means of a symptom that causes physiological suffering, brings situations of stress, leading to expressing negative feelings, generating social and spiritual discomfort. In the literature, the diagnosis of cancer is considered a tragic situation that will result in significant changes in the life and future of the people involved and especially the individual affected by the disease $\mathrm{e}^{(13-15)}$.

This diagnosis has implications in the physical, financial and interpersonal level, affecting behavior, social relationships, the perception of the patient, their families, and the prognosis of the disease. Moreover, it is usually accompanied by great psychological stress, because patients are faced with a diagnosis whose future outlook is threatened ${ }^{(2,4,15)}$. Thus, within the various treatment alternatives, the use of multidrug therapy is the most frequent one prescribed for medical care, regardless of the type of cancer ${ }^{(13,16)}$.

Chemotherapy has the function to attack the cancer cells, but they also affect normal cells of the patient with cancer, and it may cause, in most cases, alopecia, erosions of the gastrointestinal tract such as mucositis and thrush and also myelosuppression lowering the levels of the red blood cells and platelets, requiring blood transfusion according to their needs. All these side effects from the treatment, which is vital, require from the patients and their families the need to cope with it in an attempt to reduce suffering ${ }^{(5,16)}$.

The diagnosis of a disease, specifically cancer, may have an impact in various ways, as it affect the routine of the daily activities that usually presents losses and limitations. The diagnosis and treatment of this disease cause changes that, in principle, require a number of adaptations, as patients are faced with new routines and tasks they did not have before. Somatic changes caused by cancer cause many patients to become conditioned to comprehensive care, since it is a disease that often requires a long and several hospitalizations treatment with risks of complications and functional disabilities ${ }^{(16-18)}$. Such situation is evident in the statements of the second thematic axis proposed here.

From the statements, it was observed that there have been changes in the daily activities of the elderly, as well as limitations and hence the addiction to be taken care of by someone, whether family or people who are not part of the family nucleus but for some reason, are close in this hard moment. It is noticeable that cancer causes damage in social life, being expressed by the discomfort of having their leisure affected and many difficulties to maintain normal activities such as working, walking, knitting, among other practices. Still on this aspect, a restriction on the family's social life emerges, once the daily life goes through a series of changes, and feelings such as fear (of death) and anxiety with the illness ${ }^{(17)}$.

Thus, the effects of hospitalization transcend the disease and end up changing the daily life and the family structure. When a family member gets sick, usually the others are affected, which often causes tension, stress and fatigue within the family context, especially among those responsible for carrying out the care. Feelings of isolation, apathy, weeping and especially the denial in the face of therapeutic approaches ${ }^{(18)}$, may arise in the elderly facing a cancer disease. In this sense, cancer brings repercussions for that elderly patient, imposing changes, requiring social reorganization and affecting family dynamics.

\section{Conclusion}

In assessing the impact and changes in the routine of family relationships caused by the pain in elderly patients with oncological diseases through oral history, it was observed that the diagnosis of cancer and pain, which is the precursor and resulting from this 
disease, produced major physical and psychological impact on the group studied, significantly affecting the daily lives of these patients and their families.

Such fact, resulting from the long stay in a hospital environment, from the dependence on drugs, the constant irritability and loss of autonomy, as for the family members, there are abstentions of their daily activities to provide care to cancer patients, causing conflicts and feelings such as sadness, anxiety and especially the fear of loss of the family member, although the elderly tended to develop their daily activities synergistically when the pain was properly controlled.

However, they are notorious repercussions on the lives of the elderly patient, demanding social and family reorganization and the success for the treatment of pain depends, besides a multidisciplinary approach, especially nurses, the full identification of the pain complaint, selecting and evaluating strategies and responses in the care to the elderly with an oncological disease.

\section{Collaborations}

Costa JE and Simpson CA contributed for the design of the project, the development of the study, data analysis and relevant critical writing of the article and final approval of the version to be published. Mendonça AEO and Isoldi DMR contributed for the design of the project and writing. Silva RSC contributed for data analysis and writing. Silva NRC contributed for the design of the project of the study and data analysis.

\section{References}

1. Instituto Brasileiro de Geografia e Estatística. Projeção da população do Brasil e das Unidades da Federação. Brasília: Instituto Brasileiro de Geografia e Estatística; 2015.

2. Santos CA, Ribeiro AQ, Rosa COB, Ribeiro RCL. Elderly influence of gender and type of treatment on nutritional parameters in oncology. Rev Bras Cancerol. 2014; 60(2):143-50.
3. Instituto Nacional de Câncer José de Alencar Gomes (INCA). Câncer. O que é? [Internet] 2015. [citado 2015 out 22]. Disponível em: http:// www2.inca.gov.br/wps/wcm/connect/cancer/ site/oquee

4. Sallum AMC, Garcia DM, Sanches M. Acute and chronic pain: a narrative review of the literature. Acta Paul Enferm. 2012; 25(spe1):150-4.

5. Instituto Nacional de Câncer (INCA). Cuidados paliativos oncológicos: controle da dor [Internet]. 2011 [citado 2011 mar 23]. Disponível em: http:// www1.inca.gov.br/conteudo_view.asp?ID=474

6. Thernstrom M. As crônicas da dor: tratamentos, mitos, mistérios, testemunhos e a ciência do sofrimento. Rio de Janeiro: Objetiva; 2011.

7. Goodwin PJ, Bruera E, Stockler M. Pain in patients with cancer. J Clin Oncol. 2014; 32(16):1637-9.

8. Ferreira NML, Dupas G, Costa DB, Sanchez KDOL. Câncer e família: compreendendo os significados simbólicos. Ciência Cuid Saúde. 2010; 9(2):26977.

9. Fernandes MA, Evangelista CB, Platel ICS, Agra G, Lopes MSL, Rodrigues FA. The perception by nurses of the significance of palliative care in patients with terminal cancer. Ciênc Saúde Coletiva. 2013; 18(9):2589-96.

10. Meihy JCSB, Holanda F. História oral: como fazer, como pensar. São Paulo: Contexto; 2011.

11. Ministério da Saúde (BR). Secretaria de Gestão do Trabalho e da Educação na Saúde, Departamento de Gestão do Trabalho na Saúde. Técnico em hemoterapia: livro texto. Brasília: Ministério da Saúde; 2013.

12. Lamino DA, Mota DDF, Pimenta CAM. Prevalence and comorbidity of pain and fatigue in women with breast cancer. Rev Esc Enferm USP. 2011; 45(2):508-14.

13. Instituto Nacional de Câncer. ABC do câncer: abordagens básicas para o controle do câncer. Rio de Janeiro: INCA; 2011.

14. Fabiola PM, Assis FD, Vanetti TK, Sardá Junior S, Mateus WP, Giglio AD. Interventional procedures for cancer pain management. Einstein. 2012; 10(3):292-5. 
15. Barros AG, Melo MCP, Santos VEP. Meanings attributed to cancer by a group of women. Rev Enferm UERJ. 2014; 22(1):129-33.

16. Rodrigues FSS, Polidori MM. Confront and resiliency of the patients in the chemotherapeutic treatment and their families. Rev Bras Cancerol. 2012; 58(4):619-27.
17. Buetto LS, Zago MMF. Meanings of quality of life held by patients with colorectal cancer in the context of chemotherapy. Rev Latino-Am Enfermagem. 2015; 23(3):427-34.

18. Ferreira NML, Dupas G, Costa DB, Sanchez KDOL. Câncer e família: compreendendo os significados simbólicos. Ciênc Cuid Saúde. 2010; 9(2):269-77. 